\title{
CAV2 wt Allele
}

National Cancer Institute

\section{Source}

National Cancer Institute. CAV2 wt Allele. NCI Thesaurus. Code C52498.

Human CAV2 wild-type allele is located in the vicinity of 7q31.1 and is approximately $9 \mathrm{~kb}$ in length. This allele, which encodes caveolin-2 protein, plays a role in caveolae conformation. 